\title{
Identification of plant materials containing ephedrine alkaloids based on DNA barcoding and TaqMan real-time PCR assay
}

\author{
Yaqin Zheng ${ }^{1} \cdot$ Han Gao ${ }^{1} \cdot$ Ming Song ${ }^{1} \cdot$ Yunhan Lin $^{1} \cdot$ Jiajia Fan ${ }^{1} \cdot$ Yaqin Zhang ${ }^{1} \cdot$ Xia Liu $^{1}$
}

Received: 17 September 2019 / Revised: 14 June 2021 / Accepted: 28 August 2021 / Published online: 13 October 2021

(c) The Author(s) 2021

\begin{abstract}
An intentional or inadvertent mixing of plant materials containing ephedrine alkaloids, especially Ephedra, is illegal. In order to better detect plant materials containing ephedrine alkaloids in export and smuggling, DNA barcoding combined with a TaqMan real-time PCR-based assay were used in this study. We collected 201 samples from 18 species belonging to four genera distributed in three families to amplify two barcoding markers, internal transcribed spacer 2 (ITS2) and $p s b \mathrm{~A}-\mathrm{trnH}$. 175 ITS2 sequences and $136 p s b \mathrm{~A}-\operatorname{trn} \mathrm{H}$ sequences were obtained. Alignments and the neighbor-joining tree indicated that ITS2 showed a better discrimination of species than $p s b \mathrm{~A}-t r n \mathrm{H}$. In addition, based on the sequence comparison of the ITS2 region from 18 species, three sets of primer/probes were designed using the real-time PCR assay platform. A sensitivity test showed the above primer/probe sets were specific and sensitive (as little as $0.0050 \mathrm{ng} / \mu \mathrm{L}$ target DNA) to identify species containing ephedrine alkaloids. Hence, the combination of novel DNA barcoding and the TaqMan real-time PCR-based technique are promising tools for the identification of plant materials containing ephedrine alkaloids. It is beneficial to standardize market circulation and detection of plant materials containing ephedrine alkaloids.
\end{abstract}

Keywords Ephedrine alkaloids $\cdot$ Ephedra L. DNA barcoding $\cdot$ ITS2 $\cdot$ PsbA-trnH $\cdot$ TaqMan real-time PCR

\section{Introduction}

Beginning in 1995, the China Food and Drug Administration (CFDA) enacted several laws to regulate the use of ephedrine alkaloids. One of the most publically known restrictions is the policy for cold medications. More notably, the US Food and Drug Administration (FDA) Import Alert 54-13 regarding the dietary supplements and bulk dietary ingredients containing ephedrine alkaloids, which went into effect on December 14, 2012. Consequently, plant materials

Communicated by J. Van Huylenbroeck.

Yaqin Zheng and Han Gao have contributed equally to this work.

Yaqin Zhang

zhangyaqin09@163.com

$\triangle$ Xia Liu

1rx1125@126.com

Yaqin Zheng

15927143211@163.com

1 School of Chemistry, Chemical Engineering and Life Sciences, Wuhan University of Technology, Luoshi Road, Hongshan District, Wuhan 430070, China containing ephedrine alkaloids have triggered a wide concern in public health care safety around the world.

In China, plant species containing ephedrine alkaloids are generally found in the genus Ephedra, known as ma huang in Mandarin Chinese. Ephedra is the only genus in Ephedraceae, and it includes approximately 50 species around the world (Price 1996). There are ca. 14 Ephedra species in China, distributed mainly along shores, rocky beaches, and in sandy soils (Committee 1999). Apart from Ephedra (Caveney et al. 2001), some species also are known to contain ephedrine alkaloids, including Pinellia (Araceae), Typhonium (Araceae), and Sida (Malvaceae) (Caveney et al. 2001; Khatoon et al. 2005). Some species that do not contain ephedrine alkaloid and are easy to mix with ephedra herbs include Equisetum hyemale L., Equisetum ramosissimum Desf. et al.

Based upon a literature review, we identified 18 species containing ephedrine alkaloids distributed in China. Among them, Ephedra sinica Stapf, Ephedra intermedia Schrenk et C.A. Mey., Ephedra equisetina Bge., and Pinellia ternata (Thunb.) Breit. are described in the Chinese Pharmacopoeia, serving as a remedy for asthma, respiratory tract diseases, and vomiting in traditional Chinese and Indian medical 
systems (Committee 2015). Sida cordifolia Linn. is rarely used in China, but it is known as Bala in Ayurvedic medicine and widely used to treat illnesses like pulmonary tuberculosis, rheumatism, hematuria, urinary and heart diseases in India (Khatoon et al. 2005).

In addition to disease prevention, medicinal plants containing ephedrine alkaloids are widely used in health care products for fat loss, which are effective and popular, but often ephedrine alkaloids are added to these pills without proper labeling. Use in such a way may increase the risk of heart attack, stroke, and even death if misused (Haller and Benowitz 2002; Samenuk et al. 2002). Furthermore, medicinal plants containing ephedrine alkaloids have served as an important source of amphetamine in clandestine laboratories (Lee et al. 2006) and the lawless smuggling of medicinal plants containing ephedrine alkaloids continues to be a problem. Hence, it is urgent to develop a valid and sensitive method to effectively identify and detect plant materials containing ephedrine alkaloids to standardize the market circulation and ensure clinical safety.

Plant morphology and chemical analysis methods have long been used to identify plant materials containing ephedrine alkaloids (Sun et al. 2004; Kim et al. 2005; Li et al. 2008; Chatterjee et al. 2013). Nevertheless, if the diagnostic morphological features are not visible or overlooked, it is difficult to identify. For example, when the specimen is processed, it may no longer harbor its classical morphological features. Furthermore, chemical variability of the plant materials may obstruct the verification of the botanical traceability, as chemical composition varies with geographic condition and post-harvest processing (Figueredo et al. 2017).

Sequence-based technology has proven to be a powerful tool to authenticate species. DNA barcoding is diagnostic technology that uses a short, standard DNA fragments to distinguish species. It stands out for its advantages in generality and practicality without being affected by the morphological identification experience (Gu et al. 2013). In plants, the Consortium for the Barcode of Life (CBOL) recommends the combination of $m a t K$ and $r c b L$ as the core barcode. This combination has a high degree of species differentiation between genera and a low rate of species identification within genera (Hollingsworth et al. 2009). Recently, the internal transcribed spacer 2 (ITS2) has been shown to be useful in exploring systematic relatedness under genera and species (Goudsmit et al. 2003; Schultz and Wolf 2009). ITS2 sequence had an obvious advantage in the success rate of amplification and sequencing and the comparative similarity (Chen et al. 2010). And it was proposed to be a core barcode and $p s b \mathrm{~A}-t r n \mathrm{H}$ to be a complementary barcode for identifying medicinal plant species (Li et al. 2015). Many previous studies have validated that the combination of ITS2 and $p s b \mathrm{~A}-\operatorname{trn} \mathrm{H}$ possesses much more recoverability, universal sequencing applicability, and species discrimination ability (Xiang et al. 2013; Han et al. 2016; Mishra et al. 2016; Carrero and Hoyos 2018; Ha et al. 2018).

Real-time PCR is a technique that can quantify the nucleic acid copies based on different fluorescences. TaqMan realtime PCR is characterized by its high specificity and sensitivity, and has been widely applied in molecular fields such as clinical microbiology, gene expression, tumor immunology, detection of minimal residual lesions, and polymorphism (Ohst et al. 2015; Xu et al. 2016; Kading et al. 2017). Alasaad developed a TaqMan real-time PCR-based assay to identify Fasciola spp (Alasaad et al. 2011). Wu distinguished toxic Aristolochia manshuriensis from Akebia quinata to prevent renal damage using TaqMan real-time PCRbased assay (Wu et al. 2015).

In the present study, ITS2 and $p s b \mathrm{~A}-t r n \mathrm{H}$ were amplified from 201 samples, spanning four genera and three families. The Ephedra group included 128 samples from 11 species. The Araceae group contained 53 samples from four species. The Sida group included 20 samples from three species. TaqMan real-time PCR assays were conducted to detect medical plant materials containing ephedrine alkaloids. The aims of this study were to: (1) study the diversity of two barcode regions in several species and genera and (2) develop an assay to discriminate the different groups (Ephedra vs Pinellia/Typhonium vs Sida).

\section{Materials and methods}

\section{Materials}

Two-hundred and one sample belonging to Ephedra, Pinellia, Sida, and Typhonium were collected from Xinjiang, Inner Mongolia, Sichuan, Gansu, Beijing, Guangxi, Hainan, Yunnan, and Hubei Provinces (Table s1). All the samples were morphologically identified by Wei Sun at the Institute of Chinese Materia Medica, China Academy of Chinese Medical Sciences. The stem and root samples collected from the field were dried on silica gel. The majority of Ephedra collected in Xinjiang were dried naturally. All corresponding voucher samples were further deposited in the Institute of Chinese Materia Medica, China Academy of Chinese Medical Sciences, Beijing, China. Forty-five ITS2 sequences and 17 psbA-trnH sequences were downloaded from GenBank for comparative and complementary analyses (Table s2).

\section{DNA extraction}

Total genomic DNA was extracted using Plant Genomic DNA Kits (Tiangen Biotech Co., China) following the manufacturer's protocol with the following adjustments: repeated 
chloroform:isoamylol (24:1, v/v) treatment and a final DNA precipitation using ice cold isopropanol to precipitate DNA (Moyo et al. 2008).

\section{DNA amplification and sequencing using primers of ITS2 and psbA-trnH}

The ITS2 region was amplified from genomic DNA using two pairs of primers, S2F/3R or P3/E4 (Table S3) (Chen et al. 2010; Li et al. 2011). The $p s b \mathrm{~A}-t r n \mathrm{H}$ sequences were amplified using the universal primers: the psbAF and trnHR and another pair of primer fwd PA and rev TH (Table S3) (Chen et al. 2010; Li et al. 2011). The PCR reaction mixture consisted of $2 \mu \mathrm{L}(\sim 35 \mathrm{ng})$ DNA, $12.5 \mu \mathrm{L}$ of $2 \times$ Taq PCR Master Mix (Aidlab Biotechnologies Co., China), $1.0 \mu \mathrm{L}$ of $2.5 \mu \mathrm{mol} \cdot \mathrm{L}^{-1}$ forward and reverse primers, respectively (synthesized by Sangon Biotech (Shanghai) Co., China), and distilled deionized water in a final volume of $25 \mu \mathrm{L}$. General PCR conditions were conducted as previously reported (Kress et al. 2005). The PCR products were examined with $1.0 \%$ agarose gel electrophoresis and were sequenced bidirectionally using a 3730XL sequencer (Applied Biosystems, USA).

\section{Sequence analysis}

A Codon Code Aligner V 3.7.1 (CodonCode Co., USA) was used to proofread and assemble the sequencing peak diagrams. The ITS2 region was obtained based on the Hidden Markov model (HMM) to remove the 5.8S and 28S rRNA sections at both ends of the sequence on the ITS2 database (http://its2.bioapps.biozentrum.uni-wuerzburg.de/) (Keller et al. 2009). The $p s b \mathrm{~A}-t r n \mathrm{H}$ region was obtained after trimming the $p s b A$ gene and $\operatorname{trn} H$ gene by referencing the submitted sequence noted clearly in GenBank. All of the ITS2 and $p s b \mathrm{~A}-t r n \mathrm{H}$ sequences were deposited in GenBank, omitting accessions with identical sequence information. The GenBank IDs are as follows: all psbA-trnH sequences range from KX779046-KX779070, the ITS2 sequences for Ephedra range from KX779071-KX779088, and the ITS2 sequences for Sida are KX779089-KZ779111. The ITS2 sequences for Pinellia and Typonium were KM236606, KM236618, KM236622, KM236659.
To evaluate the variability and the discriminating ability, MEGA 6.0 and Clustal W were applied. And the neighborjoining (NJ) tree analysis was used for specie identification.

\section{Designed primers and probes}

To develop the TaqMan Real-time PCR, we firstly designed three groups of primers and probes. We divided the studied plant species into three groups according to their homology. In addition to the 11 studied species, another four species distributed in China without acquisition of samples, $E$. saxatilis, E. gerardiana, E. likiangensis, and E. minuta, were downloaded from GenBank to design the primers and probe for the Ephedra group. Primers and probes were designed by Applied Biosystems 7500 real-time quantitative PCR software-primer Express 3.0 using default parameters. Three groups of probes were purified using HPLC, all of the 5' ends of the oligonucleotides were attached to FAM (6-carboxyfluorescein) reporter dye, and the 3 ' ends were labeled with a TAMARA (6-carboxy-tetramethyl-rhodamine) quencher dye. Both the primers and probes were synthesized by Invitrogen (Life Technologies, China; Table 1).

To guarantee the accuracy of TaqMan Real-time PCR, the specificity of the three pairs of primers was tested as follows. The genomic DNA was firstly examined by the amplification of ITS2 region using universal primers mentioned above. Once the quality of DNA was examined, the DNA was used as template to conduct regular PCR using the designed specific primers. In Ephedra group, all the 21 haplotypes from 141 Ephedra samples and one representative sample from Pinellia and Sida were amplified using the specific primers of Ephedra group. The amplification products were inspected with gel electrophoresis. The same assays were conducted in the Pinellia and Typhonium group, Sida group.

\section{TaqMan real-time PCR assay}

Amplification reactions contained $0.5 \mu \mathrm{L}$ of $10 \mathrm{~mol} \cdot \mathrm{L}^{-1}$ primer, $0.5 \mu \mathrm{L}$ of $10 \mathrm{~mol} \cdot \mathrm{L}^{-1}$ of TaqMan probe, $10 \mu \mathrm{L}$ of $2 \times$ Goldstar TaqMan Mixture with ROX (TaKaRa Biomedical Technology (Beijing) Co. China), $1 \mu \mathrm{L}$ of DNA solution (replaced by water for negative controls), and nuclease free water in a final volume of $20 \mu \mathrm{L}$. Cycling conditions for the

Table 1 The primer and probe of three sets

\begin{tabular}{llll}
\hline Set & Left primer & Right primer & Taqman probe \\
\hline Ephedra & 5'-GCGGTCGGTTGAAATRCAR-3' & 5'-AATAAMTCCCGCCTTYGRTG-3' & 5'-TCCGACGGTGGGAGGTTGC-3' \\
Sida & 5'-GGTTGAAGTGTGGGCGGAA-3' & 5'-GAATTGACGAGCACACACGA-3' & 5'-TGGCTTCCCGTGCGCTCACC-3' \\
$\begin{array}{l}\text { Pinellia and } \\
\text { Typhonium }\end{array}$ & 5'-YGVGGGATGCGGAGAWTGG-3' & 5'-TTMYCTCSGAYGRHYGGGTT-3' & 5'-CCGYGCACAAGGRYRGGMCC-3' \\
\hline
\end{tabular}

According to the homology, the experimental species were divided into three groups. Three groups primers and probes were designed 
PCR consisted of a 10 min start up denaturation step at 94 ${ }^{\circ} \mathrm{C}$, followed by 40 cycles of amplification for $15 \mathrm{~s}$ at $94{ }^{\circ} \mathrm{C}$ and $1 \mathrm{~min}$ at $60{ }^{\circ} \mathrm{C}$.

\section{Assessment of sensitivity of the TaqMan assay}

To evaluate the specificity, all the 42 haplotypes covered 201 ephedrine alkaloids containing plant samples were used as template to develop the TaqMan Real-time PCR. The sensitivity of our assay was assessed using a tenfold dilution series (between $80 \mathrm{ng} / \mu \mathrm{L}$ and $8 \mathrm{ng} / \mu \mathrm{L}$ ) and a twofold dilution series (between $8 \mathrm{ng} / \mu \mathrm{L}$ and $0.0050 \mathrm{ng} / \mu \mathrm{L}$ ) of $E$. sinica gDNA. The detection limit was based on the final dilution at which the fluorescent signal of the TaqMan probes can still be exponentially amplified.

\section{Results}

\section{Efficiency of the PCR amplification}

In the Ephedra group, the success rates of PCR amplification of ITS2 and psbA-trnH sequences were 88.4 and $92.2 \%$, respectively. Considering Sida, the PCR amplification success rates for the two regions were both $45 \%$. However, in the Pinellia and Typhonium group, the success rate of the PCR amplification for ITS2 was $100 \%$ using the primer pair
$\mathrm{P} 3 / \mathrm{E} 4$, and $62.5 \%$ using the pair S2F/3R. The primer pair $\mathrm{PA} / \mathrm{TH}$ for the $p s b \mathrm{~A}-t r n \mathrm{H}$ region had 12.5 and $75 \%$ success amplification rates, respectively, for $P$. ternata and $P$. pedatisecta. Considering the low amplification rate for $p s b \mathrm{~A}-t r n \mathrm{H}$ in Pinellia and Typhonium, another primer pair, fwd/rev, was utilized. Nevertheless, the amplification rate success for psbA-trnH in P. ternata was 36.1 , and only $30.8 \%$ of the PCR products were sequenced. No successful amplification was obtained for $P$. cordata and T. flagelliforme using the $\mathrm{PA} / \mathrm{TH}$ and $\mathrm{fwd} / \mathrm{re}$ primer pairs.

\section{Alignment of ITS2 sequences and psbA-trnH sequences}

The GC content was calculated and variable sites were analyzed, the characteristics of the ITS2 sequences and $p s b \mathrm{~A}$ trn $\mathrm{H}$ sequences of the ephedrine alkaloids containing plants were summarized in Table 2 and Table 3, respectively.

The length of the obtained ITS 2 region from the 11 species of Ephedra in this study was 251 bp with 21 haplotypes (Figure S1). The length of the ITS2 region for $P$. ternata, $P$. cordata, $P$. pedatisecta, and $T$. flagelliforme was 251, 250, 252, and $239 \mathrm{bp}$, respectively. For these four species, the aligned length of ITS2 was $255 \mathrm{bp}$, with 16 existing haplotypes and 71 variable sites in total. The length of ITS2 among Sida species was 230 bp. Only two haplotypes and two nucleotide variation sites were detected among Sida spp.

Table 2 The characteristics of ITS2 sequences of the ephedrine alkaloids containing plants

\begin{tabular}{|c|c|c|c|c|c|c|c|}
\hline $\begin{array}{l}\text { Species } \\
\text { Name }\end{array}$ & $\begin{array}{l}\text { Sequence } \\
\text { number }\end{array}$ & $\begin{array}{l}\text { Sequence } \\
\text { length (bp) }\end{array}$ & GC content $(\%)$ & $\begin{array}{l}\text { Haplotype } \\
\text { number }\end{array}$ & $\begin{array}{l}\text { No. of vari- } \\
\text { able sites }\end{array}$ & $\begin{array}{l}\text { No. of Pi } \\
\text { sites }\end{array}$ & $\begin{array}{l}\text { No. of } \\
\text { single- } \\
\text { tons }\end{array}$ \\
\hline Ephedra sinica & 23 & 251 & 65.4 & 1 & 0 & 0 & 0 \\
\hline Ephedra intermedia & 32 & 251 & 65.4 & 3 & 2 & 0 & 2 \\
\hline Ephedra equisetina & 26 & 251 & 65.1 & 5 & 5 & 3 & 2 \\
\hline Ephedra monosperma & 9 & 251 & 65.5 & 3 & 5 & 5 & 0 \\
\hline Ephedra przewalskii & 15 & 251 & 65.2 & 2 & 1 & 0 & 0 \\
\hline Ephedra intermedia var. tibetica & 4 & 251 & 65.4 & 1 & 0 & 0 & 0 \\
\hline Ephedra distachya & 10 & 251 & 65.4 & 2 & 2 & 1 & 1 \\
\hline Ephedra glauca & 6 & 251 & 65.4 & 1 & 0 & 0 & 0 \\
\hline Ephedra regeliana & 4 & 251 & 65.3 & 1 & 0 & 0 & 0 \\
\hline Ephedra lomatolepis & 10 & 251 & 65.4 & 1 & 0 & 0 & 0 \\
\hline Ephedra fedtschenkoae & 2 & 251 & 65.0 & 1 & 0 & 0 & 0 \\
\hline Pinellia ternata & 37 & 251 & 73.8 & 11 & 7 & 3 & 4 \\
\hline Typhonium flagelliforme & 2 & 239 & 69.0 & 1 & 0 & 0 & 0 \\
\hline Pinellia cordata & 3 & 250 & 72.0 & 2 & 3 & 1 & 1 \\
\hline Pinellia pedatisecta & 14 & 252 & 73.8 & 2 & 3 & 0 & 3 \\
\hline Sida rhombifolia & 3 & 230 & 55.9 & 2 & 2 & 2 & 0 \\
\hline Sida alnifolia & 3 & 230 & 56.1 & 1 & 0 & 0 & 0 \\
\hline Sida cordifolia & 4 & 230 & 55.7 & 2 & 2 & 0 & 2 \\
\hline
\end{tabular}

In the table, ITS2 sequence number, $\mathrm{G}+\mathrm{C}$ content, sequence length, haplotype number, variable site number and other information of Ephedra group, Araceae group and Sida group were shown 
Table 3 The characteristics of $p s b \mathrm{~A}-\operatorname{trn} \mathrm{H}$ sequences of the ephedrine alkaloids containing plants

\begin{tabular}{|c|c|c|c|c|c|c|c|c|}
\hline $\begin{array}{l}\text { Specie } \\
\text { Name }\end{array}$ & $\begin{array}{l}\text { Sample } \\
\text { number }\end{array}$ & Sequence length(bp) & GC content $(\%)$ & $\begin{array}{l}\text { No. of } \\
\text { haplo- } \\
\text { type }\end{array}$ & $\begin{array}{l}\text { No. of } \\
\text { variable } \\
\text { sites }\end{array}$ & No. of Pi sites & $\begin{array}{l}\text { No. of } \\
\text { single- } \\
\text { tons }\end{array}$ & No. of deletions \\
\hline Ephedra sinica & 22 & 461 & 38.0 & 2 & 1 & 0 & 1 & $\mathrm{~N}$ \\
\hline Ephedra intermedia & 31 & 461 & 38.1 & 2 & 0 & 0 & 0 & $2 / 31$ \\
\hline Ephedra equisetina & 33 & 461,473 & 38.1 & 2 & 0 & 0 & 0 & $3 / 33$ \\
\hline Ephedra monosperma & 10 & 473 & 38.2 & 2 & 1 & 0 & 1 & $\mathrm{~N}$ \\
\hline Ephedra przewalskii & 12 & 461 & 38.0 & 1 & 0 & 0 & 0 & $\mathrm{~N}$ \\
\hline $\begin{array}{l}\text { Ephedra intermedia var. } \\
\text { tibetica }\end{array}$ & 4 & 461 & 38.0 & 1 & 0 & 0 & 0 & $\mathrm{~N}$ \\
\hline Ephedra distachya & 11 & 461 & 38.0 & 1 & 0 & 0 & 0 & $\mathrm{~N}$ \\
\hline Ephedra glauca & 4 & 461 & 38.0 & 1 & 0 & 0 & 0 & $\mathrm{~N}$ \\
\hline Ephedra regeliana & 5 & 461 & 38.0 & 2 & 0 & 0 & 0 & $2 / 5$ \\
\hline Ephedra lomatolepis & 3 & 461 & 38.0 & 1 & 0 & 0 & 0 & $\mathrm{~N}$ \\
\hline Ephedra fedtschenkoae & 3 & 473 & 38.1 & 2 & 0 & 0 & 0 & $2 / 3$ \\
\hline Pinellia ternata & 3 & 629 & 20.4 & 2 & 1 & 0 & 1 & $\mathrm{~N}$ \\
\hline Pinellia pedatisecta & 7 & 490 & 14.6 & 3 & 6 & 0 & 6 & $\mathrm{~N}$ \\
\hline Sida rhombifolia & 4 & $432-454$ & 20.6 & 4 & 17 & 10 & 6 & $3 / 4$ \\
\hline Sida alnifolia & 2 & 341 & 20.7 & 2 & 3 & 0 & 3 & $\mathrm{~N}$ \\
\hline Sida cordifolia & 3 & $375-381$ & 20.3 & 2 & 1 & 0 & 1 & $\mathrm{~N}$ \\
\hline
\end{tabular}

In the table, the $p s b \mathrm{~A}-\operatorname{trn} \mathrm{H}$ sequence number, $\mathrm{G}+\mathrm{C}$ content, sequence length, haplotype number, variable site number, insertion or deletion and other information of the Ephedra group, Araceae group and Sida group were shown. " $N$ " means no insertion or deletion in the sequence

For $p s b \mathrm{~A}-t r n \mathrm{H}$ sequences, the GC content among Ephedra species was approximately $38.0 \%$. The sequence length in eight Ephedra spp. was $461 \mathrm{bp}$, and the sequence length was 473 bp in E. fedtschenkoae and E. monosperma. However, the length $p s b \mathrm{~A}-t r n \mathrm{H}$ in E. equisetina was $461 \mathrm{bp}$ and $473 \mathrm{bp}$. From the multiple sequence alignments of $p s b \mathrm{~A}$ trn $\mathrm{H}$ of Ephedra, we found that the differences consisted of insertions, deletions, and single nucleotide changes. Therein, only $E$. sinica showed a C/T transition (1/19) and E. monosperma showed $\mathrm{A} / \mathrm{C}$ transversion (4/10). Notably, the single nucleotide was a "C" at site 300 in E. monosperma in the four $p s b \mathrm{~A}-t r n \mathrm{H}$ sequences obtained from individuals collected in Sichuan, while sequences from individuals collected in Xinjiang and Gansu read as "A". Compared with the corresponding $p s b \mathrm{~A}-t r n \mathrm{H}$ sequence downloaded from GenBank, deletions or insertion of 12 bases were found in E. intermedia, E. regeliana and E. fedtschenkoae, which was the base "TTGGATTTCCTG". In all the 33 psbA$t r n \mathrm{H}$ sequences of E. equisetina, 3 experimental sequences existed 12 bases deletion compared with other experimental sequences and those downloaded by GenBank.

\section{Phylogenetic analysis}

In this study, a phylogenetic tree based on Kimura 2 parameter (K2P) model was constructed for both ITS2 and psbA$\operatorname{trn} \mathrm{H}$ sequences. The $\mathrm{NJ}$-tree based on ITS2 sequences demonstrated that the three groups clustered into three clades (Fig. 1). In the Ephedra clade, the haplotypes of $E$. intermedia, E. przewalskii, E. distachya dispersed to different group. The remaining nine Ephedra species clustered into one subclade. In the Pinellia and Typhonium clade, four species grouped into four subclades, illustrating monophyly for these genera. The three Sida species included in this study grouped into one clade.

The NJ tree based upon $p s b \mathrm{~A}-t r n \mathrm{H}$ sequences was constructed without $P$. cordata and $T$. flagelliforme, as no sequences were available on GenBank or obtained in our study (Fig. 2). The psbA-trnH NJ tree showed that Ephedra, Sida, Pinellia, grouped into three clades. Seventeen haplotypes of 11 Ephedra species grouped into one clade, with no subclades, and $P$. ternata and $P$. pedatisecta grouped into two branches. Four species of Sida clustered together.

\section{The specificity of the designed primers}

The ITS2 regions of all the 42 haplotypes of ephedrine alkaloids containing plant materials, including Ephedra, Pinellia, Typhonium and Sida, were successfully amplified firstly (Figure S2). We demonstrated that the genomic DNA was successfully extracted and could be used as templates to evaluate the specificity of primers. All 21 haplotype samples from Ephedra generated PCR products of $166 \mathrm{bp}$, 


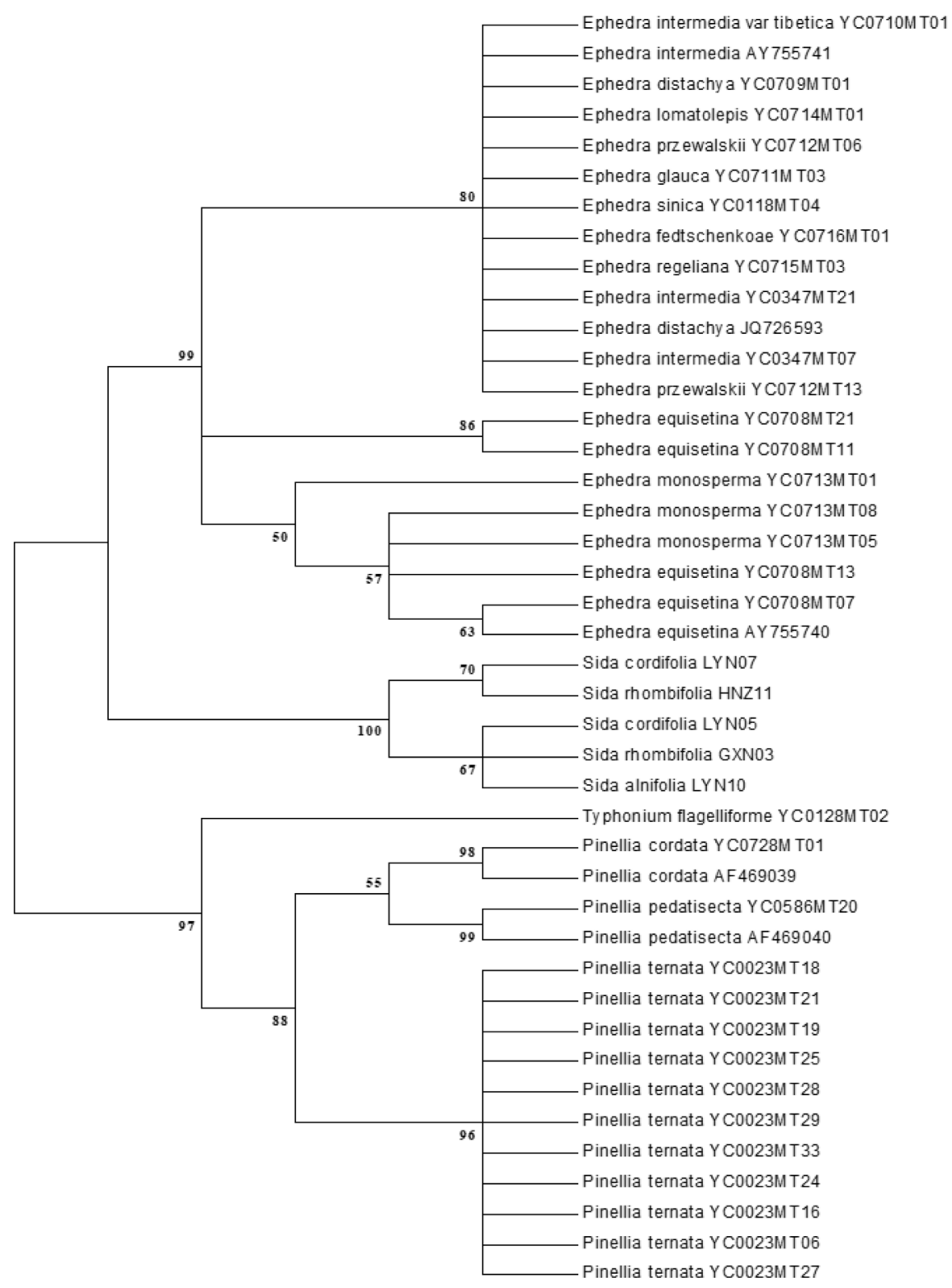

Bootstrap was repeated for 1000 times, and the results showed that the self-developing support rate was $\geq 50 \%$

Fig. 1 The NJ tree of plant materials containing ephedrine alkaloids constructed with ITS2 sequences

showing a band between 100 and $250 \mathrm{bp}$, while samples from Pinellia and Typhonium group, Sida group did not generate an amplicon (Fig. 3). A fragment of 168 bp was amplified using the specific primers of Pinellia and Typhonium group, while samples from Ephedra and Sida showed no bands (Fig. 4). In the Sida group, the same result was found (Fig. 5), which illustrated three pairs of primers of three groups were specific.

\section{Rapid and sensitive detection of plant materials containing ephedrine alkaloids using TaqMan qPCR}

Based on the results of the specific primers (Table 1), we found that these primers can specifically amplify the DNA of three groups. On the basis, we designed the probes (Table 1) and conducted the Real-time PCR assays. All 11 Ephedra species included in this study showed normal fluorescence with the primers and probe, but no amplifications were 


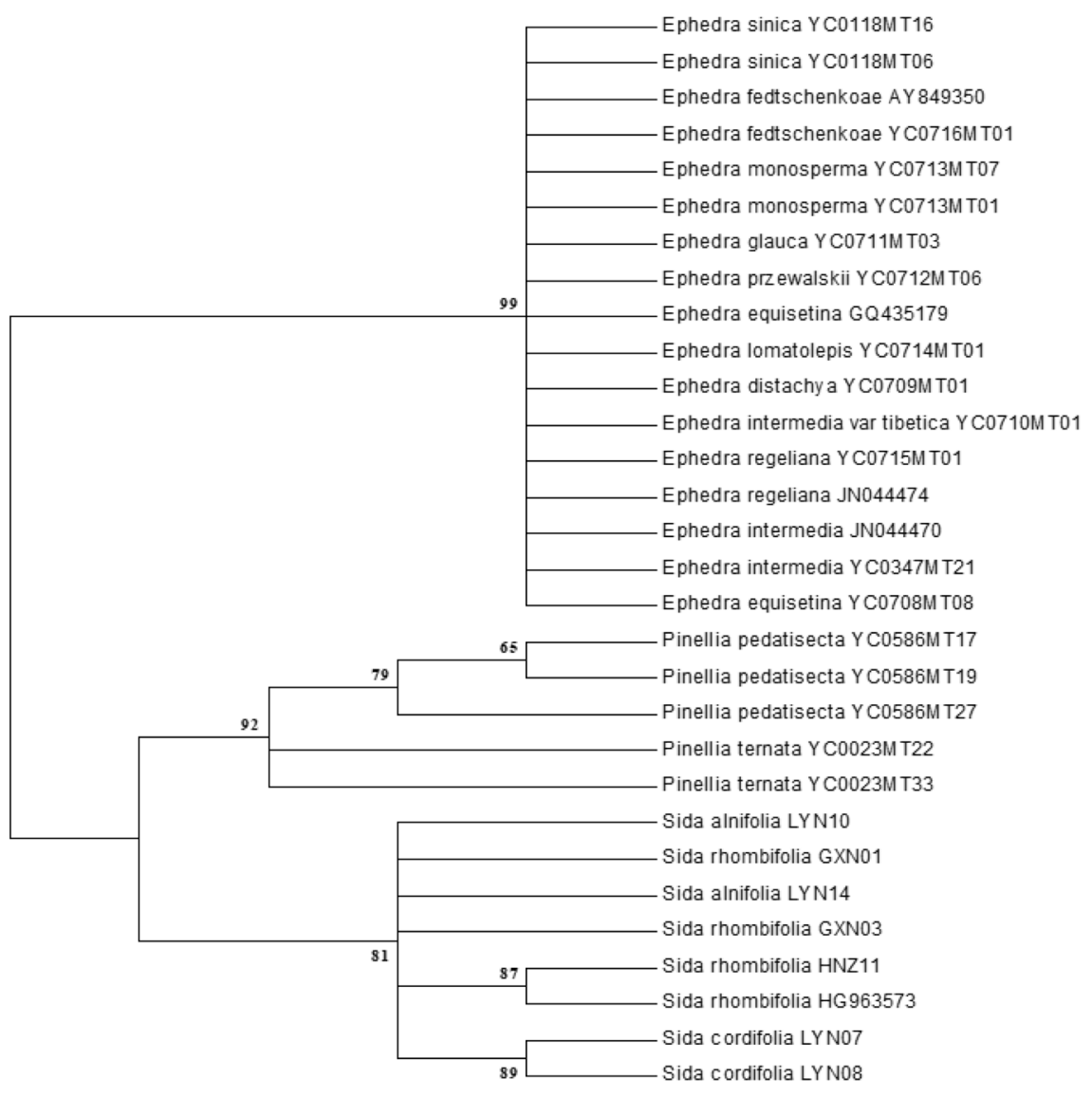

Bootstrap was repeated for 1000 times, and the results showed that the self-developing support rate was $\geq 50 \%$

Fig. 2 The NJ tree of plant materials containing ephedrine alkaloids constructed with $p s b \mathrm{~A}-\operatorname{trn} \mathrm{H}$ sequences

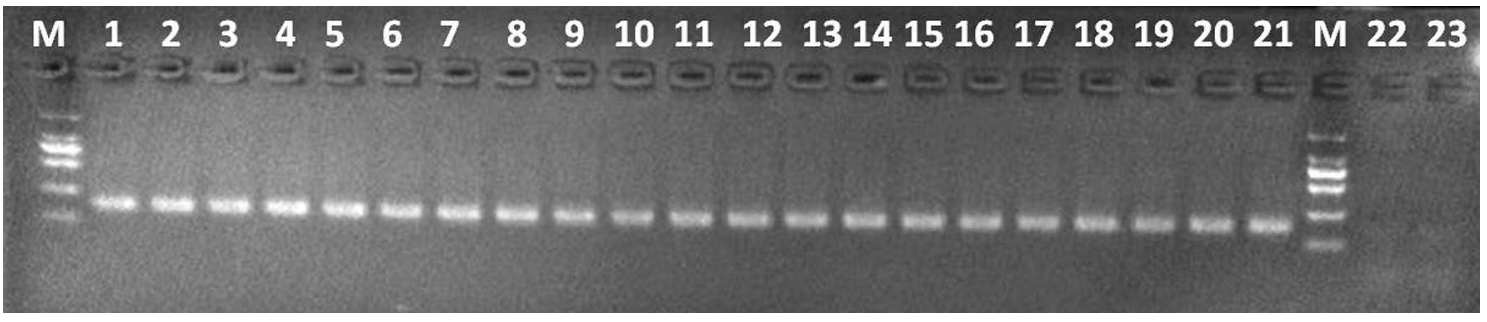

Fig. 3 The specific assay of primers of Ephedra group. M: DL2000;1: Ephedra sinica; 2-4: three haplotypes of Ephedra intermedia; 5-9: five haplotypes of Ephedra equisetina; 10-12: three haplotypes of Ephedra intermedia; 13-14: two haplotypes of Ephedra

observed with the primers and probe from the Pinellia and Typhonium group or the Sida group. Four species of Pinellia and Typhonium showed normal fluorescence amplification only when the primers and probe from the Pinellia and Typhonium group was used. The same is true for the Sida przewalskii; 15: Ephedra intermedia var. tibetica; 16-17: two haplotypes of Ephedra distachya; 18: Ephedra glauca; 19: Ephedra regeliana; 20: Ephedra lomatolepis; 21: Ephedra fedtschenkoae; 22: one haplotype of Pinellia ternate; 23: one haplotype of Sida rhombifolia

group. Results from the Real-time PCR showed that all haplotypes generated normal fluorescence amplification curves with $\mathrm{CT}<35$.

The results of a series TaqMan qPCR assays on diluted genomic DNA of $E$. sinica showed that fluorescence 


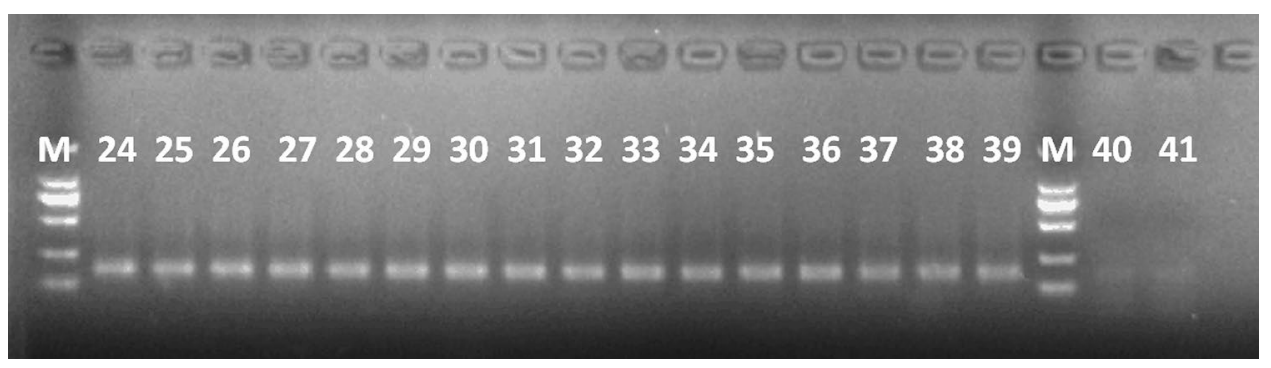

Fig. 4 The specific assay of primers of Pinellia and Typhonium group. M: DL2000; 24-34: eleven haplotypes of Pinellia ternate; 35: Typhonium flagelliforme; 36-37: two haplotypes of Pinellia cordata;

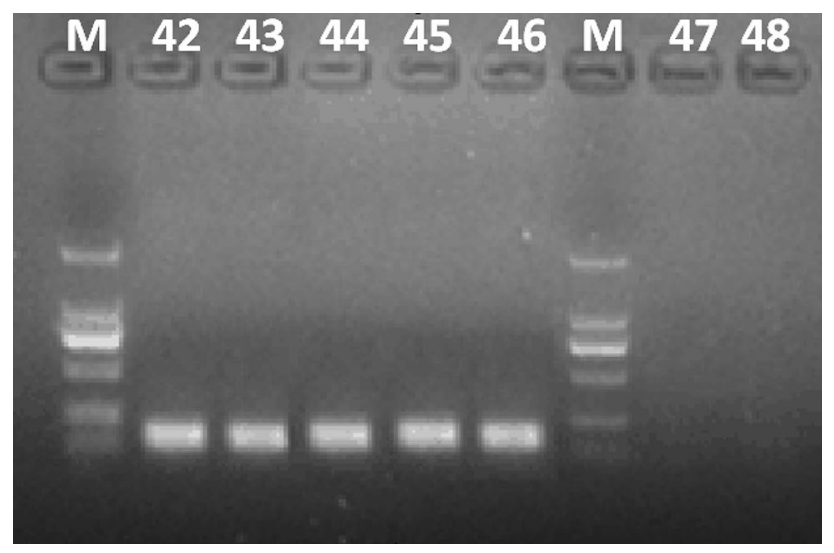

Fig. 5 The specific assay of primers of Sida group. M: DL2000; 42-43: two haplotypes of Sida rhombifolia; 44: Sida alnifolia; 45-46: two haplotypes of Sida cordifolia; 47: Ephedra sinica; 48: one haplotype of Pinellia ternate

amplification curves were exponential at $0.0050 \mathrm{ng} /$ $\mu \mathrm{L}$ and the fluorescence signal was no longer normal at $0.0025 \mathrm{ng} / \mu \mathrm{L}$. This indicated that the minimum amount of genomic DNA of $E$. sinica detected with the TaqMan qPCR was about $0.0050 \mathrm{ng} / \mu \mathrm{L}$ (Figure S3).

\section{Discussion}

\section{The comparison of the ITS2 and psbA-trnH barcodes used for identification of ephedrine alkaloid containing species}

An ideal barcode should be easily amplified and sequenced (Taberlet et al. 2007). In the present study, 175 ITS2

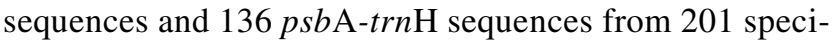
mens of 18 species were obtained, indicating that the utilized ITS 2 primers are more universally applicable and
38-39: two haplotypes of Pinellia pedatisecta; 40: Ephedra sinica; 41: one haplotype of Sida rhombifolia

can be utilized to trace botanical origin from ephedrine alkaloid containing plant species. This can be attributed to several reasons: (i) the length of ITS2 is much smaller than $p s b A$-trnH, varying between 230 and $252 \mathrm{bp}$, which makes it easier to amplify and sequence; (ii) The efficiency of PCR amplification and sequencing of ITS2 is higher than $p s b \mathrm{~A}-t r n \mathrm{H}$; and (iii) High-quality sequencing peak diagrams of $p s b \mathrm{~A}-t r n \mathrm{H}$ of Sida were difficult to obtain because of the existence of poly A or T sequence.

The $p s b \mathrm{~A}-t r n \mathrm{H}$ region is more applicable to distinguish Ephedra, as the entire region is highly conserved, and $E$. monosperma, E. equisetina, and E. fedtschenkoae individuals had unique insertions, which could be used for identification purposes. The stable single change at site 300 in E. monosperma could provide geographical information because the $p s b \mathrm{~A}-t r n \mathrm{H}$ sequences from $E$. intermedia, $E$. regeliana, and $E$. fedtschenkoae did not match the psbAtrn $\mathrm{H}$ sequences obtained from GenBank. However, the 12 base insertion or deletion could be due to geographical variation (Lahaye et al. 2008) or pseudogene amplification. For E. sinica, E. glauca, E. lomatolepis, E. distachya, E. intermedia var. tibetica, and E. przewalskii, both ITS2 and $p s b \mathrm{~A}-t r n \mathrm{H}$ sequences proved inappropriate to differentiate among species. A more informative barcode is needed to distinguish these species.

In this study, we did not experiment with easily mixed species that did not contain ephedrine. Because compared to ephedrine-containing species, their genetic distance and sequence are quite different. Our results indicated that two universal primer pairs, PA/TH and fwd/rev, showed no successful amplification and sequencing in $P$. cordata and $T$. flagelliforme, which suggested that more applicable primers need to be designed. 


\section{DNA barcoding and TaqMan probe technology were used to trace the ephedrine alkaloid containing plant materials}

A previous study documented that specific primers based on the difference of $p s b \mathrm{~A}-t r n \mathrm{H}$ in Ephedra can identify Ephedra DNA in dietary supplements using PCR (Techen et al. 2006). However, in our work, $p s b \mathrm{~A}-\operatorname{trn} \mathrm{H}$ cannot be amplified and successfully sequenced in several species. In addition, some species also had no referenced $p s b \mathrm{~A}-t r n \mathrm{H}$ sequences in GenBank. ITS2 stood out for its universality and accessibility. Therefore, we selected ITS2 to design primers and probes. The TaqMan assay was specific and sensitive enough to detect as little as $0.0050 \mathrm{ng} / \mu \mathrm{L}$ of DNA in our samples. In addition, under normal PCR conditions, results showed no smeared or invisible bands when visualized using electrophoretic analysis at $\sim 0.0050 \mathrm{ng} / \mu \mathrm{L}$ of DNA.

\section{The significance of using DNA barcoding and TaqMan probe technology}

Although the supervision and administration of medical plant materials containing ephedrine alkaloids are strict, cases of smuggling are still prevalent. The identification of medical plant materials containing ephedrine alkaloids is of great importance not only for ensuring safety but for controlling reasonable market circulation. The present work developed a rapid, specific, and highly sensitive method to detect plant materials containing ephedrine alkaloids. We tested 18 species in this study, covering the most common medical species containing ephedrine alkaloids in China, and more than $90 \%$ of the ephedrine alkaloid containing plant species listed on the FDA Poisonous Plant Database and European Food Safety Authority. Because of our large sample size, we had a high success rate in identifying existing ephedrine-containing species. If new ephedrine-contained species appear, the false positive or false negative results might occur due to the lack of database information. In case of false negative result, we need to further sequence the new species and determine whether these primers and probes are suitable for them by comparing the sequence information with the current ephedrine-containing species. For the false positive result, we could further detect the content of ephedrine by chemical method to ensured the accuracy of result.

\section{Conclusion}

In this paper, we evaluated the feasibility of the ITS 2 and psbA-trnH region as candidate barcodes to discriminate the 201 ephedrine alkaloids containing samples. ITS2 proved advantageous over $p s b A$-trnH. Further, based on DNA barcoding, we developed a specific and sensitive TaqMan realtime PCR assay (as little as $0.0050 \mathrm{ng} / \mu \mathrm{L}$ target DNA) to distinguish plant species containing ephedrine alkaloids. Our study demonstrated that DNA barcoding along with TaqMan technology can be used to detect plant materials containing ephedrine alkaloids rapidly and sensitively. This study could be an assistant method to detect plant materials containing ephedrine alkaloids. In particular, it may also have general guiding implications in the examination of dietary supplements and ephedrine alkaloid containing powdered materials.

Author contribution statement $\mathrm{YZ}$ and $\mathrm{HG}$ analyzed the data and wrote the manuscript; MS, YL and JF collected the materials and performed the experiments; XL and YZ designed and guided experiments. All the authors agreed on the contents of the paper and have no conflicting interests to declare.

Supplementary Information The online version contains supplementary material available at https://doi.org/10.1007/s11738-021-03304-3.

Acknowledgements This research was supported by the Major Scientific and Technological Special Project for "Significant New Drugs Creation" (No. 2014ZX09304307).

Open Access This article is licensed under a Creative Commons Attribution 4.0 International License, which permits use, sharing, adaptation, distribution and reproduction in any medium or format, as long as you give appropriate credit to the original author(s) and the source, provide a link to the Creative Commons licence, and indicate if changes were made. The images or other third party material in this article are included in the article's Creative Commons licence, unless indicated otherwise in a credit line to the material. If material is not included in the article's Creative Commons licence and your intended use is not permitted by statutory regulation or exceeds the permitted use, you will need to obtain permission directly from the copyright holder. To view a copy of this licence, visit http://creativecommons.org/licenses/by/4.0/.

\section{References}

Alasaad S, Soriguer RC, Abu-Madi M, El Behairy A, Jowers MJ, Banos PD et al (2011) A TaqMan real-time PCR-based assay for the identification of Fasciola spp. Vet Parasitol 179(1-3):266-271. https://doi.org/10.1016/j.vetpar.2011.01.059

Carrero D, Hoyos R (2018) Molecular identification and genetic diversity of Lutzomyia gomezi (Diptera: Psychodidae) using DNA barcodes in Cordoba. Colomb Trop Biomed 35(1):100-110

Caveney S, Charlet DA, Freitag H, Maier-stolte M, Starratt AN (2001) New observations on the secondary chemistry of world ephedra (ephedraceae). Am J Bot 88(7):1199-1208

Chatterjee A, Kumar S, Chattopadhyay SK (2013) A validated HPLCPDA method for identification and quantification of two bioactive alkaloids, ephedrine and cryptolepine, in different Sidaspecies. 
Biomed Chromatogr 27(12):1720-1725. https://doi.org/10.1002/ bmc. 2985

Chen S, Yao H, Han J, Liu C, Song J, Shi L et al (2010) Validation of the ITS2 region as a novel DNA barcode for identifying medicinal plant species. PLoS One 5(1):e8613

Committee (1999) Flora of China. Science Press, Beijing

Chinese Pharmacopoeia Commission (2015) Chinese pharmacopoeia. China Medical Science Press, Beijing

Figueredo G, Özcan MM, Chalchat JC, Chalard P, Çelik B, Özcan MM (2017) The effect of harvest years on chemical composition of essential oil of Basil (Ocimum minimum L.) leaves. J Essent Oil Bear Plants 20(6):1-5

Goudsmit N, Coleman E, Seckinger R, Wolitzky R, Stanford A, Corcoran C et al (2003) A brief smell identification test discriminates between deficit and non-deficit schizophrenia. Psychiatry Res 120(2):155-164. https://doi.org/10.1016/S0165-1781(03)00194-X

Gu W, Song J, Cao Y, Sun Q, Yao H, Wu Q et al (2013) Application of the ITS2 region for barcoding medicinal plants of Selaginellaceae in pteridophyta. PLoS One 8(6):e67818. https://doi.org/10.1371/ journal.pone. 0067818

Ha TT, Huong NT, Hung NP, Guiguen Y (2018) Species identification using DNA barcoding on processed Panga catfish products in Viet Nam revealed important mislabeling. Turk J Fish Aquat Sci 18:457-462

Haller CA, Benowitz NL (2002) Adverse cardiovascular and central nervous system events associated with dietary supplements containing ephedra alkaloids. N Engl J Med 343(25):1833-1838

Han J, Pang X, Liao B, Yao H, Song J, Chen S (2016) An authenticity survey of herbal medicines from markets in China using DNA barcoding. Sci Rep 6:18723. https://doi.org/10.1038/srep18723

Hollingsworth P, Forrest L, Spouge J, Hajibabaei M, Ratnasingham S, Chase M et al (2009) A DNA barcode for land plants. Proc Natl Acad Sci 106(31):12794-12797. https://doi.org/10.1073/pnas. 0905845106

Kading RC, Wadhwa A, Wilkins K, Gao J, Gigante CM, Zhao H et al (2017) A pan-lyssavirus Taqman real-time RT-PCR assay for the detection of highly variable rabies virus and other lyssaviruses. PLOS Negl Trop Dis 11(1):e0005258

Keller A, Schleicher T, Schultz J, Muller T, Dandekar T, Wolf M (2009) 5.8S-28S rRNA interaction and HMM-based ITS2 annotation. Gene 430(1-2):50-57. https://doi.org/10.1016/j.gene.2008. 10.012

Khatoon S, Srivastava M, Rawat A, Mehrotra S (2005) HPTLC method for chemical standardization of Sidaspecies and estimation of the alkaloid ephedrine. J Planar Chromatogr-Mod TLC 18(105):364367. https://doi.org/10.1556/JPC.18.2005.5.5

Kim HK, Choi YH, Erkelens C, Lefeber AW, Verpoorte R (2005) Metabolic fingerprinting of ephedra species using $1 \mathrm{H}-\mathrm{NMR}$ spectroscopy and principal component analysis. Chem Pharm Bull 53(1):105-109

Kress WJ, Wurdack KJ, Zimmer EA, Weigt LA, Janzen DH (2005) Use of DNA barcodes to identify flowering plants. Proc Natl Acad Sci 102(23):8369-8374

Lahaye R, van der Bank M, Bogarin D, Warner J, Pupulin F, Gigot G et al (2008) DNA barcoding the floras of biodiversity hotspots. Proc Natl Acad Sci 105(8):2923-2928

Lee JS, Han EY, Lee SY, Kim EM, Park YH, Lim MA et al (2006) Analysis of the impurities in the methamphetamine synthesized by three different methods from ephedrine and pseudoephedrine.
Forensic Sci Int 161(2-3):209-215. https://doi.org/10.1016/j.forsc iint.2006.02.054

Li YW, Zhou FQ, Zhang SP, Li ZY, Kong QY (2008) Studies on morphology and histology of Pinellia pedatisecta. Chin Med Mat 31(2):206-209

Li D, Liu J, Chen Z, Wang H, GE X, Zhou S et al (2011) Plant DNA barcoding in China. J Syst Evol 49(3):165-168. https://doi.org/ 10.1111/j.1759-6831.2011.00137.x

Li X, Yang Y, Henry RJ, Rossetto M, Wang Y, Chen S (2015) Plant DNA barcoding: from gene to genome. Biol Rev 90(1):157-166. https://doi.org/10.1111/brv.12104

Mishra P, Kumar A, Nagireddy A, Mani DN, Shukla AK, Tiwari R et al (2016) DNA barcoding: an efficient tool to overcome authentication challenges in the herbal market. Plant Biotechnol J 14(1):821. https://doi.org/10.1111/pbi.12419

Moyo M, Amoo SO, Bairu MW, Finnie JF, Van Staden J (2008) Optimising DNA isolation for medicinal plants. S Afr J Bot 74(4):771775. https://doi.org/10.1016/j.sajb.2008.07.001

Ohst T, Kupsch C, Gräser Y (2015) Detection of common dermatophytes in clinical specimens using a simple quantitative realtime TaqMan polymerase chain reaction assay. Br J Dermatol 174(3):602-609. https://doi.org/10.1111/bjd.14198

Price RA (1996) Systematics of the gnetales: a review of morphological and molecular evidence. Int J Plant Sci 157(6 Suppl):S40-S49

Samenuk D, Link MS, Homoud MK, Contreras R, Theohardes TC, Wang PJ (2002) Adverse cardiovascular events temporally associated with ma huang, an herbal source of ephedrine. Mayo Clin Proc 77(1):12-16. https://doi.org/10.4065/77.1.12

Schultz J, Wolf M (2009) ITS2 sequence-structure analysis in phylogenetics: a how-to manual for molecular systematics. Mol Phylogenet Evol 52(2):520-523. https://doi.org/10.1016/j.ympev.2009. 01.008

Sun S, Zhou Q, Liu J, Huang H (2004) Study on the identification of standard and false BanXia by two-dimensional infrared correlation spectroscopy. Spectrosc Spect Anal 24(4):427-430

Taberlet P, Coissac E, Pompanon F, Gielly L, Miquel C, Valentini A et al (2007) Power and limitations of the chloroplast trnL (UAA) intron for plant DNA barcoding. Nucleic Acids Res 35(3):e14. https://doi.org/10.1093/nar/gk1938

Techen N, Khan IA, Pan Z, Scheffler BE (2006) The use of polymerase chain reaction (PCR) for the identification of ephedra DNA in dietary supplements. Planta Med 72(3):241-247

Wu L, Sun W, Wang B, Zhao H, Li Y, Cai S et al (2015) An integrated system for identifying the hidden assassins in traditional medicines containing aristolochic acids. Sci Rep 5(1):11318

Xiang L, Song J, Xin T, Zhu Y, Shi L, Xu X et al (2013) DNA barcoding the commercial Chinese caterpillar fungus. FEMS Microbiol Lett 347(2):156-162. https://doi.org/10.1111/1574-6968.12233

Xu H, Ma Y, Zhang Y, Pan Z, Lu Y, Liu P et al (2016) Identification of cathepsin $\mathrm{K}$ in the peritoneal metastasis of ovarian carcinoma using in-silico. Gene Expression Analysis Journal of Cancer 7(6):722-729

Publisher's Note Springer Nature remains neutral with regard to jurisdictional claims in published maps and institutional affiliations. 